\title{
AFTER FIFTY YEARS OF THE \\ FEDERAL RULES OF GIVIL PROCEDURE: ARE THE BARRIERS TO JUSTIGE BEING RAISED?
}

\section{JACK B. WEINSTEIN†}

Today we celebrate the adoption, just fifty years and three weeks ago, of our Federal Rules of Civil Procedure. The Rules formally went into effect on September 16, 1938, after Congress declined to modify or reject them. ${ }^{1}$ They had been transmitted by the Supreme Court to the Attorney General on December 20,1937, and in turn by the Attorney General to Congress on January 3,1938. ${ }^{2}$ They were the offspring of the Rules Enabling Act, finally passed by Congress in 1934 after twenty years of battle in the Senate and elsewhere. ${ }^{3}$

It is fitting that these proceedings should have been arranged by Professor Subrin with the aid of so many other eminent proceduralists, including as discussion leaders Professors Burbank, Carrington, Silberman, Shapiro, and Rosenberg. While adoption of the Rules Enabling Act was due to the work of political figures like Taft, Shelton, Hughes, and Cummings, ${ }^{4}$ the initial success of the Civil Rules largely resulted from the drafting and theoretical work of academics like Clark, Moore, and Sunderland. And the vitality of the Rules has been, in large measure, the result of work of academic reporters and members of the Advisory Committee, like Professors Carrington, Kaplan, Miller, and Sacks.

Jurists may be tempted to apply their own versions of procedure

† Judge, United States District Court, Eastern District of New York; Adjunct Professor of Law, Columbia University Law School. I greatly appreciate the assistance of my law clerk, Jonathan B. Wiener, Harvard Law School class of 1987.

1 See Chandler, Some Major Advances in the Federal Judicial System, $1922-$ 1947, 31 F.R.D. 307, 512 (1963).

2 See Letter of Submittal from Honorable Charles Evans Hughes to Honorable Homer Cummings (Dec. 20, 1937), in LeTter From the AtTORNEy General Transmitting the "Rules of Givil Procedure for the District Courts of The United States," H.R. Doc. No. 460, 75th Cong., 3d Sess. at v. (1938); Supreme Court Adopts Rules for Civil Procedure in Federal District Courts, 24 A.B.A. J. 97, 97 (1938).

${ }^{3}$ See Chandler, supra note 1, at 484-85; Roosevelt Signs Court Rules Bill, N.Y. Times, June 20, 1934, at 2, col. 3. As subsequently revised, the Rules Enabling Act now is codified at 28 U.S.C. $§ 2072$ (1982). See Weinstein, The Ghost of Process Past: The Fiftieth Anniversary of the Federal Rules of Civil Procedure and Erie, 54 BROOKLYN L. REV. 1, 8-17 (1988).

- See Weinstein, supra note 3 , at 4 . 
at times. It has been the continuing stream of critical law review writings typified by those of professors who are present at this meeting that have kept judges from wandering too far. The standard treatises, like Wright $\mathcal{E}$ Miller and Moore, and a host of casebooks and monographs have stressed the Federal Rules. Partly because of the economics of publishing and partly because of the pressure to write and teach on national subjects, almost every law school's procedure courses are based on national practice. Typically, students carry the Federal Rules to class and those Rules provide the first critical lesson in interpreting a major piece of integrated "statutory" law.

Very few of our more than half-a-million practicing lawyers have escaped this exposure. Federal judges in their initial training schools and conferences are taught by the same professors who are teaching their prospective law clerks.

That common source of literature and training has given the Federal Rules an influence far greater than would be expected from the relatively small proportion of civil cases in which they are applicable. It is one of the reasons that every drafter of state rules looks to the Federal Rules as a baseline.

This enormous peer pressure and common background has prevented flexibility and discretion, the equitable powers of judges wearing "Chancellor's Boots," from creating the excessive centrifugal forces that might have led to unacceptable differences in practice among federal district courts and judges. There is as little variation in the size of our chancellors' feet as in the height of Lilliputians; one stretch sock fits all. There are, of course, variations in personality and approach of federal judges that are reflected in their attitudes towards civil procedure-activists like Pollack, Will, and Schwarzer just naturally demand more of lawyers than passive types like Keeton and myself. In the main, a federal practitioner will be comfortable in her knowledge of the Federal Rules in any federal court.

Now there is a great debate over the system of federal civil justice. Who and what kinds of cases should be welcomed or discouraged from entering the federal courts? What disputes heretofore in federal tribunals should be forced to go to state courts or to alternate forms of dispute resolution? Should our current civil practice, in which self-policing by lawyers often governs litigation, be modified to require federal judges to take control, more on the order of the German system? ${ }^{6}$

B Burbank, The Chancellor's Boot, 54 BrooklyN L. Rev. 31, 33-34 (1988) (commenting on Weinstein, supra note 3 , and expressing soundly conceived worry about too much equity and too little law in federal procedure).

${ }^{\circ}$ But see Allen, Kock, Riechenberg \& Rosen, The German Advantage in Civil 
Should more be demanded of pleaders in the way of precision and detail? Can litigants be made to be more precise about their claims and evidence earlier in the litigation by means of summary judgment or other devices? Do sanctions and controls by the court cost more or less than they are worth because of the satellite litigation and other payments they entail? How should judges be spending their time in view of the fact that about ninety percent of the cases will be disposed of essentially by the litigants? To what extent can we rely upon the economic cost of litigation and good faith of lawyers to control discovery abuses? What are abuses and how extensive are they? What are the qualitative and other effects of constantly expanding our judicial system to meet heavier caseloads? What are the effects on society of what we do or do not do in the courts? How can we-or should we-have more law and less equity, more rules and less discretion? Should we control local court rules and, if so, how? Is Professor Judith Resnik of Southern California right when she says federal judges are too managerial or is Professor Hans Smit of Columbia correct when he asserts that they are not nearly assertive enough? Should complex multi-district, multi-party litigation be vastly federalized as proposed by current drafts of the American Law Institute Complex Litigation Project?

How can we get the field data to answer these questions, particularly when so few opinions are written and professors do not have time to visit the courts and law firms to see what really is occurring? Professor Rosenberg will address some of these fact-finding problems. As Chief Judge of the Eastern District of New York, I encouraged studies of our court operations. Professor Margaret Berger's massive empirical study on discovery practice, for example, will take a number of years. I must confess, nevertheless, that I often lacked the data needed for intelligent control of even the interstitial rules we could make in the district court.

When I graduated from law school in 1948, ten years after the Rules became operative, few of these questions were burning issues. Yet already in the mid-forties, the Federal Rules were driving common law and state practice from most curriculums.

Nineteen eighty-eight is not only the fiftieth anniversary of the Federal Rules, but also the twenty-fifth anniversary of New York's Civil Practice Law and Rules (CPLR), which I had the honor of helping draft. When Harry Tweed appointed me Reporter on the revision

Procedure: A Plea for More Details and Fewer Generalities in Comparative Scholarship, 82 Nw. U.L. Rev. 705, 722 (1988) (disputing the view that German judges "dig" for the facts and arguing that the plaintiff and defendant actually determine the scope of the litigation). 
of the New York practice, Professor/Judge Charles Clark, the Reporter to the original Federal Rules drafting committee, invited me down to the Second Circuit. He took me to lunch in the old judges' dining room. There he offered some pointed and heated advice along with the tepid soup. The Federal Rules were not quite twenty years old then, and Judge Clark instructed that what was to be the new CPLR must follow exactly the federal practice. I knew that this would not be possible since the Federal Rules rely in no small degree on an underlying state practice. New York's legal system had its own problems-it handled more cases than the entire federal system and had a longer history. Having dealt already with members of the New York bar, bench, and legislature, I also was skeptical of my ability to make them swallow a wholesale transplantation of the federal system to New York, particularly in view of the intermediate appeals practice and the difference in the bar's attitude towards state judges. But I kept silent as Judge Clark explained what I was to do. As we were talking, Learned Hand stopped by-the powerful, small, bushy-eyebrowed master. Clark introduced me as the person who was going to revise the New York practice, whereupon Hand snapped to attention, swept his fingers to his forehead, and said "Sir, I salute you for your bravery!"

I was startled by this response to what I believed would be a technical, almost pedantic, task. It was not until some months later that I began to understand Judge Hand's reaction. One day I picked up the Law Journal to find a review of my modest proposed departures from the Federal Rules for the CPLR. The front-page article was a violent attack on the draft written by none other than Charles Clark. Proceduralists are often hot-blooded as well as long-winded.

I appear before you, then, as a veteran of the procedure wars. I know what it is to draft one's own cherished version of the rules, what it is to criticize someone else's, and what it is to face public excoriation. By now I have had a couple of decades of learning, teaching, and applying the Federal Rules in my own court, some experience on the Advisory Committee on the Federal Rules of Evidence, and a period to reflect and write on procedural rulemaking from a somewhat dispassionate point of view. ${ }^{7}$ Nevertheless, the sense that I, or anyone else, has found the perfect procedural solutions eludes me.

This is an anniversary and so the history of the last fifty years must play a crucial role in our thinking. "A lawyer without history or

7 See J. Weinstein, Reform of Court Rule-Making Procedures at $\mathbf{x}$ (1977); Weinstein, Reform of Federal Court Rulemaking Procedures, 76 ColUM. L. REv. 905, 962-64 (1976); Weinstein, Reform of the Federal Rule-making Process, 63 A.B.A. J. $47,47-48$ (1977). 
literature is a mechanic, a mere working mason."8 It is not from the perspective of history alone, however, that I want to comment today. The story of the fight for the merger of law and equity in one streamlined practice, and its culmination in our Rules, has been well told elsewhere. ${ }^{\circ}$

This conference is not only a retrospective celebration of the great experiment begun fifty years ago, but the opportunity to shape and nurture the next fifty years of American civil practice. It would be a waste of all this room's collected proceduralist ${ }^{10}$ brainpower to dwell solely on history. Churchill asks: "History with its flickering lamp stumbles along the trail of the past, trying to reconstruct its scenes, to revive its echoes, and kindle with pale gleams the passions of former days. What is the worth of all this?"11 The answer for our gathering is that while history can and must inform our debate, it is not worth the entire conference. Academic members of this conference and their students will be the evolving architects of the next generation's civil practice. So let this commemoration be a commencement day as well as a day of celebration.

The Rules are youthful, alive, and well. We should exchange congratulations for the great success of the last half century, and joyously usher the spirit of the Rules into the next. They are worth fighting over their merits, for they affect the lives of our fellow citizens. We are

W. SCOTT, GuY MANnering ch. 37, at 259 (1964).

- See, e.g., Burbank, The Rules Enabling Act of 1934, 130 U. PA. L. REv. 1015, 1023-24 (1982) (focusing on legislative history); Chandler, supra note 1, at 488-98 (describing general history beginning with Major Tolman's report to the advisory committee in June, 1935); Subrin, How Equity Conquered Common Law: The Federal Rules of Civil Procedure in Historical Perspective, 135 U. PA. L. REv. 909, 944, 973 (1987) (reviewing "procedural history"); Weinstein supra note 3, at 4-15 (reviewing the history of the Enabling Act's "antecedent travail"); see also C. WRIGHT, THE LAw OF THE FEDERAL COURTS 399-408 (4th ed. 1983) (reviewing general history beginning with Judiciary Act of 1789); C. Wright \& A. Miller, Federal. Practice and Procedure $\S \S 1001-08$ (1987) (EXAMINING GeNERAL HISTORY BEgINNING WiTH COMPaRisons to ENGlish Procedure).

${ }_{10}$ By "proceduralists" I do not mean a breed of narrow-minded legal militarists committed to notions of perfect procedure at odds with social needs, as Professor Coffee has insinuated bemusedly. See Coffee, The Regulation of Entrepreneurial Litigation: Balancing Fairness and Efficiency in the Large Class Action, 54 U. CHI. L. REv. 877,877 (1987) ("Just as war is too important to be left to generals, civil procedure-with apologies to Glemenceau-is too important to be left to proceduralists."). Rather, I mean to embrace thinkers of diverse backgrounds and professional stations in the proceduralist community, just as this conference includes representatives of faculty, bench and bar, with widely disparate expertise and viewpoints. I agree with Professor Coffee that the shaping of procedure can benefit only from open and wide-ranging debate.

${ }^{11}$ W. Churchill, Tribute to Neville Chamberlain before the House of Commons (Nov. 12, 1940), reprinted in 1 The WaR SPeeches of Winston S. Churchill. 299 (C. Eade compiler 1951). 
not here to bury the Federal Rules, but to praise them and contend over how they can improve to make our law available to all.

I always expected that "reformers" would work for improvements for all, especially the least fortunate. But of late something seems awry. There appears to be a continuing-and, I believe, intensifying-struggle for control over the federal courts between those who would vindicate the Federal Rules' aim of smooth and relatively easy access to our tribunals and those who would erect procedural and other barriers to entry. Curiously, it is the courts, not Congress, expressing this restrictive view. ${ }^{\mathbf{1 2}}$ Congress is resisting the pleas of the United States Judicial Conference to abolish diversity, encouraging plaintiffs to use the courts through litigation cost-shifting devices such as Section 1988 and the Equal Access to Justice provisions, ${ }^{13}$ and increasing standing through environmental and many other statutes. ${ }^{14}$

The erection of barriers to court access under the guise of procedural efficiency seems misguided and shortsighted: it will burden the weak and the aggrieved unfairly, and it ultimately will undermine the legitimacy of the legal system which most of these "reformers" hold dear.

Few disagree that the Federal Rules were intended by their drafters to open wide the courthouse doors. The authors sought to air out the courts and let the sunlight of substance shine into them; they were sweeping away the dirt and cobwebs built over centuries of tinkering with process. They employed for this task some available tools-horizontal national uniformity, broader judicial discretion, and the fusion of law and equity. The drafters' commitment was to a civil practice in which all parties would have ready access to the courts and to relevant information, a practice in which the merits would be reached promptly and decided fairly. Every claimant would get a meaningful day in court. In the golden age of federal civil procedure, the federal courthouse was the beacon to which those with serious substantive grievances could turn for direction toward justice.

We may debate the Rules' success in this brash venture to obtain

12 See Wells, Is Disparity a Problem?, 22 GA. L. REv. 283, 283-84, 335-36 (1988) (noting the Supreme Court's effort to keep cases in state court and out of federal court, with the result that state interests are defeating claims of federal constitutional rightholders more frequently than in the past).

135 U.S.C. $\S 504$ (1982); 42 U.S.C. § 1988 (1982); see also Bartell, Federal Court Awards of Attorneys' Fees, in 2 ALI-ABA Resource Materials, Civil Practice and Litigation in Federal and State Courts 1269, 1284, 1358 (4th ed. 1987).

${ }_{14}$ See Beers, Standing and Related Procedural Hurdles in Environmental Litigation, in 1 ALI-ABA Course of STUdy: ENVIRONMENTAL Litigation 1, 13-17 (1988). 
equal justice for all, but the point of the venture-increasing access-is quite clear. The most persistent and able modern critics of the 1938 Rules-among them Professors Subrin and Burbank-have helped to firmly establish this historical proposition. ${ }^{15}$

The controversy that surrounds us today seems to me to be about the desirability of free entry to our courts, but politically sensitive fundaments rarely are labelled forthrightly by their detractors. ${ }^{16}$ The issue is raised in a variety of somewhat disingenuous guises, camouflaged under values like "administrative efficiency." There are two empirical thrusts to the anti-access movement: the relentless trumpeting of a purported "litigation explosion" and a new attack on the degree to which current federal practice resembles the Rules drafters' original plan. Neither hits the mark.

Concern over excess litigation in the federal courts is old hat. Modern critics like Judges Bork and Posner and Justice Scalia say a "litigation explosion" has taken place since $1960,{ }^{17}$ but even in 1960 prominent jurists like Chief Justice Warren and Judge Wyzanski were complaining about the crisis of federal court congestion. ${ }^{18}$ Before our Revolution, Sir Edmund Burke warned that "the colonists should be watched closely because they [are] a very litigious people-they [already have] purchased more copies of Blackstone than had been sold in all of England."19

Concern over excess litigation in the federal courts is also typically

15 See Burbank, supra note 9, at 1045-46 (drawing this conclusion from a discussion of the appointment of the Special Committee to Suggest Remedies and Formulate Proposed Laws to Prevent Delay and Unnecessary Cost in Litigation); Subrin, Federal Rules, Local Rules, and State Rules: Uniformity, Divergence, and Emerging Procedural Patterns, 137 U. PA. L. REv. 1999, 2005 (1989) ("Uniform federal rule enthusiasts cited statistics of the high percentage of procedural issues on appellate dockets, asserting that procedure kept substantive law from being applied.").

${ }_{16}$ See Chase, Civil Litigation Delay in Italy and the United States, 36 AM. J. Comp. L. 41, 86 (1988) (noting that unlike most American "reformers," the "Italian reformers are of interest [because of] . . . their willingness to recognize the political ingredients of procedural rule making"); Wells, supra note 12, at 283 (complaining of "a sort of implicit pact not to discuss matters with which no one feels comfortable").

${ }^{17}$ See R. Posner, The Federal Courts: Crisis and Reform 65, 80 (1985); Bork, Dealing with the Overload in Article III Courts, 70 F.R.D. 231, 232 (1976); Scalia, Remarks . . Before the Fellows of the American Bar Foundation and the National Council of Bar Presidents (Feb. 15, 1987), quoted in Galanter, The Life and Times of the Big Six; or, the Federal Courts Since the Good Old Days, 1988 WIS. L. REv. 921, 921-22.

18 See Galanter, supra note 17, at 927-28.

18 Bell, Commentary at the Proceedings of the National Conference on the Causes of Popular Dissatisfaction with the Administration of Justice (Apr. 8, 1976) (paraphrasing Burke), reprinted in The Pound Conference: Perspectives on Justice IN THE Future 124-25 (A. Levin \& R. Wheeler eds. 1980) [hereinafter The Pound CONFERENCE]. 
exaggeration. Sober attention to the statistical evidence indicates that we are no more overwhelmed now than at many times in the past. For example, the Rand studies demonstrate that the total "amount of tort litigation nationwide is growing relatively slowly. Indeed, when the rate is adjusted for population growth, it sinks . . . to a modest 3 percent."20 The Rand analysis shows that relatively routine personal injury suits, such as auto cases, are steady or declining, while large complex mass injury cases have the greatest potential for growth. ${ }^{21}$ The rapid increase in product liability tort actions in the federal courts may be a one-time spurt, occasioned by the unknowing exposure of victims many years ago to substances causing latent injury. Now that science is discovering these illnesses and the law is adjusting liability regimes, we may expect deterrence and settlements to stabilize the litigation flow. Moreover, the growth in products disputes appears to be centered around a very few substances-such as asbestos, Bendectin, and the Dalkon Shield-suggesting that the rise in filings is unique and quite manageable. ${ }^{22}$ In any event, these large cases are the kind best suited to federal litigation. ${ }^{23}$

Beyond tort cases, the pattern of litigation reflects a rather sad irony. Professor Galanter's careful decomposition of the federal filings rates into categories of cases shows that over forty percent of the growth in filings since 1960 is a result of quite recent policies pursued by the conservative administration in Washington: an emphasis on recovery of student loans and veterans' benefits, denials of social security benefits, and an increase in prisoner populations. ${ }^{24}$ The program of stinginess in benefits and harsh law-and-order incarcerations is thus the direct cause of a large part of the rise in federal filings. We may see even greater

20 D. Hensler, M. Vaiana, J. Kakalik \& M. Peterson, Trends in Tort Litigation: The Story Behind the Statistics 6 (1987) (Rand Institute for Civil Justice Special Report).

${ }^{21}$ See id. at 8-11. Compare Galanter, supra note 17, at 937 (noting a "dramatic relative decline in the most routine of tort cases") with AMERICAN LAW INSTITUTE, Complex Litigation Project 21-22 (Council Draft No. 1, 1988) ("The causes of complex litigation . . . show no sign of diminishing, and the volume of multi-party, multi-forum cases consequently is likely to continue to rise.").

${ }^{22}$ See United States General. Accounting Office, Product Liability: Extent of "Litigation Explosion" in Federal Courts Questioned 2 (Jan. 1988); see also Galanter, supra note 17, at 941-42 (arguing that because the major movements of the product liability category reflect the ebb and flow of specific subpopulations of cases, "there is ample ground for skepticism about the use of federal court product liability filing figures as an indicator of the propensity to bring product liability claims . . . or as a portent of the general growth of litigation" (footnote omitted)).

${ }^{23}$ See Weinstein, Procedural and Substantive Problems in Complex Litigation Arising From Disasters, 5 Touro L. REV. 1, 2-3 (1989).

${ }^{24}$ See Galanter, supra note 17, at 925 (Table 1); id. at 926 (Fig. 2). 
leaps in prisoner petitions as the Administration's Sentencing Guidelines expand prison ranks further. ${ }^{25}$

The truth about the "litigation explosion" is that it is a weapon of perception, not substance. If the public can be persuaded that there is a litigation crisis, it may support efforts to cut back on litigation access. Professor Coffee notes that the "crisis" mentality's basis in fact will become irrelevant "because the perception itself may be the important phenomenon, one that can become self-fulfilling." 26 Professor Burbank likewise laments that the "rhetorical tendency of the "litigation explosion' story is to deflect attention from values other than efficient administration in the effort to end the 'crisis,' dam the 'flood,' or stem the 'avalanche." "27 It is that "perception," he says, that animated the 1980 and 1983 amendments to the Rules, aimed at restricting access to the courts. ${ }^{28}$ Professor Rotunda concludes that the "increased talk of the litigation crisis may tell us more about the public relations expertise of insurance companies than anything else."29

The "explosion" idea is wrong as a matter of fact: by relatively modest increases in our trial bench and magistrates, ${ }^{30}$ we have maintained roughly the same number of cases per judge as we had in $1960 .^{31}$ And it is wrong as a matter of policy: if cases are growing in the federal courts, so be it! That is what judges and courts are there to do: to hear cases. We are public servants pledged to do justice, not exalted elites who bless the masses with such bites of judicial time as we deign to dole out. If some judges truly are overburdened, then the first resort should be to add judges ${ }^{\mathbf{3 2}}$ or to add support staff, ${ }^{33}$ not to shut

${ }^{25}$ See Weinstein, A Trial Judge's First Impression of Federal Sentencing Guidelines, 52 Al.B. L. Rev. 1, 1 (1989).

${ }^{26}$ Coffee, No Exit?: Opting Out, The Contractual Theory of the Corporation, and the Special Case of Remedies, 53 BrookLyN L. Rev. 919, 920 (1988).

${ }^{27}$ Burbank, The Costs of Complexity (Book Review), 85 Mich. L. REv. 1463, 1468 (1987).

${ }^{28}$ See Burbank, The Transformation of American Civil Procedure: The Example of Rule 11, 137 U. PA. L. REv. 1925, 1955 (1989).

${ }^{29}$ Rotunda, ABA Offers Trite Reforms to Defuse Fictional Litigation Crisis, Manhattan Lawyer, Aug. 16-22, 1988, at 12.

30 See Weinstein \& Wiener, Of Sailing Ships and Seeking Facts: Brief Reflections on Magistrates and the Federal Rules of Civil Procedure, 62 ST. JoHN's L. REv. $429,437-39$ (1988) (discussing magistrates' extensive role in the federal system).

31 See Rotunda, supra note 29, at 12.

32 Cf. Clark, Adjudication to Administration: A Statistical Analysis of Federal District Courts in the Twentieth Century, 55 S. GAL. L. REv. 65, 129-30 \& n.301 (1981) (implying that court congestion in the late $1950 \mathrm{~s}$ was due to a sharp decline in judicial appointments).

33 See Chase, supra note 16, at 54 (noting that according to Judge Posner, the addition of non-judicial support staff has permitted the federal courts to accept additional filings). 
the courthouse door. On balance, the social costs of adding personnel are likely to be much smaller than the social costs of frustrating important civil and commercial rights.

The second empirical thrust of the anti-access movement is the proposition that the drafters' goals have been missed. The argument goes that the drafters chose inter-district uniformity and trans-substantive uniformity as their ultimate goals, and that at least the first has failed to be achieved. A primary exponent of this view is Professor Subrin. ${ }^{34}$ Professor Subrin in his detailed analyses supposes that the Rules drafters deemed uniformity a "transcendental good whose inherent value required no explanation," $"$ and observes that little uniformity exists in much modern day procedure. Both characterizations seem overstated.

The proponents of the Rules Enabling Act were not interested in uniformity for its own sake; they saw uniformity as a tool for streamlining litigation and for arriving promptly at an assessment of the merits. Thomas Shelton initially spoke about uniformity as a means toward homogenizing procedure, but by 1918 he had made clear that he valued uniformity for its ability to make procedure the mere conduit of the merits-"a clean pipe, an unclogged artery, a clear viaduct, or a bridge." ${ }^{36}$ William Howard Taft's agenda was not uniformity per se, but "expedition and thoroughness in the enforcement of public and private rights in our courts," 37 thus " "cheapening the cost of litigation by simplifying judicial procedure and expediting final judgment." "38 Roscoe Pound thought procedure should be "mere etiquette," never interfering with the direct consideration of the merits. ${ }^{39}$ This is hardly the kind of thinking that insists on procedural uniformity for its own sake regardless of the consequences for the merits. An original impetus for the Rules was the belief that by reducing unnecessary litigation over procedural points, they would reduce court congestion. ${ }^{40}$ When the liberals began to back the Enabling Act in the 1930s, it was because they sought substantive decision-making, not mere uniformity. Roosevelt's new Attorney General, Homer Cummings, wanted the courts to dispense with technicalities and assist in the interpretation and implemen-

st See Subrin, supra note 15, at 2043-44.

3s Id. at 2001 .

36 Subrin, supra note 9, at 951 (attributing the metaphors to T. SHELToN, SPIRIT OF THE CourTs 17, 32, 72 (1918)); see also Burbank, supra note 9, at 1065-66.

37 A. Mason, William Howard TafT: Ghief Justice 88-89 (1964).

${ }^{38} I d$. at 114 (quoting Senate Journal, 61st Cong., 3d Sess. 13).

${ }^{39}$ See Subrin, supra note 9, at 946-47.

10 See A. MASON, supra note 37, at 115. 
tation of new national legislation. ${ }^{41}$

Similarly, the drafters of the Rules did not deify uniformity. They employed uniformity and simplicity as tools to cultivate smooth substance-oriented litigation. As Professor Subrin himself has documented: "Throughout his life, [Charles] Clark kept repeating that procedure should be subservient to substance, a means to an end, the 'handmaid not the mistress' to justice." 42 The numerous permissions in the Rules for local imagination ${ }^{43}$ make clear that simplicity and workability, not uniformity, were paramount.

Consequently, it is no disgrace to the Rules to find incomplete judge-to-judge uniformity. We should strive for uniformity where it enhances simplicity and streamlines procedure. Efforts at harmonizing local rules and at modeling state procedure on federal practice are quite valuable, but some measure of local variation is not unhealthy. It may even be a necessary feature if the Rules are to progress: we need some latitude for experimentation, and we need to let individual judges feel they are not straight-jacketed by the current consensus interpretation of ambiguous national rules. Federal judges are by and large an intelligent and creative lot and a little experimentation on their part invigorates our practice. Reduce initiative enough and we make the job unattractive to those who should be judges. Academics above all others should understand this need for independence and imagination. Whatever the curriculum may say, we each run our classrooms to satisfy our individual visions.

In any event, I take issue with the impression that appropriate uniformity is absent from modern federal procedure. ${ }^{44}$ In my view, there is sufficient uniformity of practice, much more than one might have expected in 1938. The principal source of this uniformity is one not anticipated by the Rules' drafters and largely ignored by modern detractors: the powerful centripetal force of national legal education. As I have noted already, in the past few decades law schools have increasingly taught civil procedure from the Federal Rules. Major texts and treatises on procedure and evidence are virtually all based on federal practice, almost to the complete exclusion of code and common law

41 See Subrin, supra note 9, at 969 \& n.357.

42 Id. at 962; see also Clark, The Handmaid of Justice, 23 WASH. U.L.Q. 297, 297 (1938) (quoting In re Coles, 1 K.B. 1, 4 (1907) (Collins, M.R.), as saying "the relation of rules of practice to the work of justice is intended to be that of a handmaid rather than mistress...").

43 See, e.g., FED. R. Crv. P. 40 (allowing local calendar systems); FED. R. CIV. P. 83 (allowing local rules not inconsistent with the Federal Rules).

14 Subrin not only admits that one kind of uniformity, trans-substantive, has flowered-he complains about it. See Subrin, supra note 15, at 2043. 
practice. Every year we graduate a new cohort of young attorneys who are steeped in federal procedure; they think first of pursuing every case in federal court and must pass an increasingly nationalized bar exam. The result is that almost every lawyer in the nation thinks in terms of the Federal Rules, even if she spends time practicing in state courts. To quote Professor Shapiro: "The Federal Rules have not just survived; they have influenced procedural thinking in every court in this land (and in some other lands), and indeed have become part of the consciousness of lawyers, judges, and scholars who worry about and live with issues of judicial procedure."45

Federal judges now receive regular training and indoctrination from the Federal Judicial Center emphasizing national uniformity. The growth of large national law firms and an increasingly nationalized substantive law have given sustenance to a growing national legal culture. Taken together, these pedagogic and sociological forces dwarf the uniformity-retarding influences of local rules and experimentation. Education, not sanctions, is the device most helpful in improving practice.

Finally, it is not especially persuasive to argue that the Rules as prescribed in 1938 were excessively equity-oriented for that time. ${ }^{46} \mathrm{Al}$ though the drafters probably did not foresee it fully, the subsequent fifty years have proved remarkably serendipitous. The Rules' provisions for broad joinder and discovery and their receptivity to large complex cases have jibed well with legal history since World War II: the rapid expansion of national legislation on labor, civil rights, the environment, banking, commerce, and other fields; the growth of interstate commerce and the concomitant growth of diversity disputes; the rise of a national bar and telecommunications; the increasing ability of science to investigate mass illness and injury, especially latent disease; the commitment to equal treatment requiring law to mean the same thing in one forum as in another. The Rules could not have been designed much better to accommodate these developments. Hence, criticism of the original equity-based construction of the Rules seems to me to miss the point. The Rules, as amended over the years to meet new problems, are what we need today.

On this point some current "reformers" insist that the Rules should be undergoing a critical metamorphosis to procedures differing significantly by types of cases. Professor Burbank-for whose superb

45 Shapiro, Federal Rule 16: A Look at the Theory and Practice of Rulemaking, 137 U. PA. L. REv. 1969, 1969 (1989).

46 See, e.g., Subrin, supra note 9, at 922 (stating that "the drafters made an enormous change: . . . the Federal Rules went beyond equity's flexibility and permissiveness"). 
work on Rule 11 and other areas we are grateful-argues that the recent amendments "render[] an assessment [of the Rules] in terms of claims and stated aspirations in 1938 or 1934, let alone 1926, an exercise in nostalgia, if not irrelevancy." ${ }^{37}$ If by this he means that the Rules are no longer compatible with open access to the courts and prompt treatment of the merits, his views may be premature and "wishful thinking." 48 Professor Burbank and I agree that access should not be denied; our disagreement relates primarily to appropriate degrees of discretion.

Even if the amendments of the 1980s derive from an anti-access spirit-and I believe they do-the basic structure of the Rules remains robust. The original ideals of the Rules, coupled with the fortunate American history I have just described, have only strengthened them over time. The federal courts are today a more powerful engine of justice than ever before. We must resist what Professor Chase calls "the cynicism which accepts [exclusion and delay] . . . as inevitable."49 Amendments tarnishing our judicial system should be repealed or revised, not incorporated into self-fulfilling mischaracterizations.

Let me turn to what I suggested at the outset may be the misguided and shortsighted "reforms" that recently have been proposed and occasionally implemented. The most obvious examples include the recent amendments to Rule 11, which a Third Circuit Committee, relying on the excellent field work of Professor Burbank, estimates have been decidedly anti-plaintiff in practice. In that circuit Rule 11 sanctions reportedly are awarded almost three times as often against plaintiffs as against defendants, and nine times as often against civil rights plaintiffs as against civil rights defendants. ${ }^{50}$ Judge Carter's thoughtful and useful paper for this conference analyzes the special Rule 11 problems of civil rights plaintiffs. ${ }^{51}$ Given his experience as a leading civil rights litigator for the NAACP, as well as his depth of judicial experience, Judge Carter's impression seems especially valuable. $\mathrm{Nu}$ merous other commentators also have noted Rule 11's pernicious effects. $^{52}$

17 Burbank, supra note 28 , at 1928 (footnote omitted).

18 Burbank, supra note 5 , at 33 .

49 Chase, supra note 16 , at 87 .

so See Burbank, supra note 28, at 1937-38. Professor Burbank guesses that the statistics would be even more anti-plaintiff in the Seventh Circuit. See id. at 1957.

s1 See Carter, The Federal Rules of Civil Procedure as a Vindicator of Civil Rights, 137 U. PA. L. REv. 2179, 2183, 2191-95. (1989) (filings of civil rights cases have dropped in the wake of the Rule 11 amendment).

${ }^{32}$ See T. Willging, The Rule 11 Sanctioning Process 9-10 (Fed. Jud. Center 1988); Cavanagh, Developing Standards Under Amended Rule 11 of the Federal Rules of Civil Procedure, 14 Hofstra L. REv. 499, 536 (1986); Vairo, Rule 11: 
A second door swinging shut is the class action provision of Rule 23. It is not clear why, but federal class action filings have plummeted in the last few years, from over 3000 in 1975 to about 600 in the year ending June $31,1987 .{ }^{53}$ Judge Carter suggests that the decline is due to new attorneys' fee doctrines, ${ }^{54}$ but that probably cannot explain the entire drop. Perhaps some judicial hostility to class-wide relief suits has deterred new filings, but it is too early to say.

The Supreme Court's recent trilogy of cases ${ }^{55}$ interpreting Rule 56 undoubtedly will add to the difficulties plaintiffs face in getting to trial. The decisions essentially allow a defendant to require the plaintiff quickly to assemble and present its case at great expense in order to survive a motion for summary judgment. ${ }^{56}$ Perhaps Dean Carrington's proposal to amend Rule 56 with a provision for judicial "establishment of fact and law" could restore balance to this situation. ${ }^{57}$

The development of new pleading rules for specialized kinds of cases is a throwback to the technicalities embodied in the old code pleading rules and so pointedly abolished by the 1938 Rules. Specialized pleadings may be appropriate in certain discrete areas of litigation, such as patent cases, but that is not where they are being proposed. The new pleading "reforms" are aimed at erecting obstacles to plain-

A Critical Analysis, 118 F.R.D. 189, $195-97$ (1989); Note, Plausible Pleadings: Developing Standards for Rule 11 Sanctions, 100 HARv. L. REv. 630, 632 (1987).

${ }^{83}$ See Martin, The Rise and Fall of the Class-Action Lawsuit, N.Y. Times, Jan. 8,1988 , at B7, col. 3 (filings of class actions have fallen from 3,061 in 1975 to 610 in the year ending June 30, 1987); see also Lundquist, The Climate has Changed Will the Dinosaurs Survive? in The New Amendments to the Federal Rules of Civil. Procedure 110, 111-13 (P. Rothstein ed. 1983).

se See Carter, supra note 51, at 2188-90.

ss See Celotex Corp. v. Catrett, 477 U.S. 317, 322 (1986) ("Rule 56(c) mandates the entry of summary judgment, after adequate time for discovery and upon a motion, against a party who fails to make a showing sufficient to establish the existence of an element essential to that party's case."); Anderson v. Liberty Lobby, Inc., 477 U.S. 242, 249 (1986) ("[T]here is no issue for trial unless there is sufficient evidence favoring the nonmoving party for a jury to return a verdict for that party. . . ."); Matsushita Elec. Indus. Co. v. Zenith Radio Corp., 475 U.S. 574, 595-98 (1986) (remanding antitrust case in which defendants had no apparent economic motive to conspire to lower prices for summary judgment unless plaintiff could rebut presumption that prices were cut for competitive reasons).

${ }^{86}$ See Risinger, Another Step in the Counter-Revolution: A Summary Judgment on the Supreme Court's New Approach to Summary Judgment, 54 BROOKLYN L. REv. $35,38-39$ (1988) (calling the burden of predicting a case's development from preliminary information the "price of admission" required of a moving party); see also Childress, A New Era for Summary Judgments: Recent Shifts at the Supreme Court, 116 F.R.D. 183, 191 (1987) (arguing that recent Supreme Court decisions create a standard favoring parties moving for summary judgment).

s7 See Carrington, Making Rules to Dispose of Manifestly Unfounded Assertions: An Exorcism of the Bogy of Non-Trans-Substantive Rules of Civil Procedure, $137 \mathrm{U}$. PA. L. Rev. 2067, 2094-2105 (1989). 
tiffs in civil rights and RICO suits, among others. ${ }^{58}$ Expansion of this trend will deal a serious blow to the Rules' successful trans-substantive streamlining of procedure. Some use of separate tracks for different kinds of cases may be desirable, so long as it does not inhibit necessary litigation.

We also can see building support for restrictions on discovery. Some management of discovery is probably necessary; leaving discovery as a game among the parties alone creates incentives for rational but abusive cost-imposing tactics. ${ }^{58}$ But with attentive and firm management by a judge or magistrate, it is my experience and belief that almost all discovery abuse can be controlled or prevented. ${ }^{60}$ The federal magistrate can be extraordinarily useful in supervising civil discovery. In my district, we typically refer discovery in every civil case to a magistrate, and our results have been encouraging. ${ }^{\text {61 }}$ Professor Silberman's paper at this conference will discuss some aspects of the use of magistrates and masters in major complex litigation. ${ }^{62}$ She cautions against

${ }^{58}$ See Marcus, The Revival of Fact Pleading Under the Federal Rules of Civil Procedure, 86 Colum. L. REv. 433, 447-50 (1986); Subrin, supra note 9, at 984.

${ }^{69}$ The Rules contemplate that much of pre-trial litigation will be run by "the lawyers themselves" without "full judicial control." Weinstein, Standing Masters to Supervise Discovery in the Southern District, New York, 23 F.R.D. 36,38 (1958). This less-supervised stage may permit some misconduct; although some inherent features of the bar tend to limit discovery abuse, even in the absence of judicial monitoring, other features tend to foster abuse. See J. Setear, The Barrister and the Bomb: The Dynamics of Cooperation, Nuclear Deterrence, and Discovery Abuse 2 (Civil Liability Program of the Center for Studies in Law, Economics, and Public Policy, Yale Law School, Working Paper No. 75, Mar. 1988) (unpublished manuscript) (on file with the University of Pennsylvania Law Review) (analyzing the discovery process using game theory). Yet compared to the Continental European system in which the judge controls discovery, the American party-controlled system does not appear to increase court delay. See Chase, supra note 16, at 82-83 (comparing the American system to the Italian and German systems).

${ }^{60}$ Given attorneys' self-restraint and a healthy dose of control by a magistrate, discovery abuse is usually quite manageable. See J. Weinstein, What Discovery Abuse? Comments on John Setear's "The Barrister \& the Bomb" 5-9 (Conference on Issues in Civil Procedure: Advancing the Dialogue, Program on Civil Liability, Yale Law School, Apr. 8-9, 1988) (unpublished manuscript) (on file with the University of Pennsylvania Law Review) (stating that discovery is not simply a two-party game; judges and magistrates exert a controlling influence).

61 See Weinstein \& Wiener, supra note 30, at 436-41 (discussing value of magistrates); see also Resnik, Failing Faith: Adjudicatory Procedure in Decline, $53 \mathrm{U}$. CHI. L. REv. 494, 548-49 (1986) (discussing discovery abuse in general and the attempted solutions employed in the Eastern District of New York); Standing Orders of the Court on Effective Discovery in Civil Cases, 102 F.R.D. 339 (E.D.N.Y. 1985) (effective March 1, 1984; as amended February 27, 1987). The original 1984 Orders were published at 102 F.R.D. 339, along with the Revised Report of the Special Committee on Effective Discovery in Civil Cases for the Eastern District of New York, 102 F.R.D. at 357.

${ }^{62}$ See Silberman, Judicial Adjuncts Revisited: The Proliferation of Ad Hoc Procedure, 137 U. PA. L. REv. 2131 (1989). 
the use of non-judicial officers to manage litigation as a substitute for judicial control. I, nevertheless, remain quite optimistic about the limited use of masters and magistrates, particularly in large and complex cases.

What is troubling about recent proposals for discovery reform is the advocacy of severe cost-shifting and information-concealing amendments. Judge Easterbrook has suggested automatic shifting of discovery request costs to the losing party, so that parties expecting to lose will not make purely harassing requests. ${ }^{63}$ Such a system would seriously burden moderate-income plaintiffs whose suits of necessity have a low subjective probability of success until after discovery is completed. Thus, for example, asbestos plaintiffs under such a system never would have risked seeking the reams of documents that eventually uncovered manufacturers' early knowledge of asbestos' harms. ${ }^{64}$ Professor Donald Elliot of Yale suggested last spring that a defendant ought to be given an initial opportunity to provide all documents it thought relevant, after which the plaintiff would pay for all further discovery requests. ${ }^{65}$ This proposal seems alarmingly skewed.

The recent history of Rule 16 is confusing. Some courts of appeals have permitted iron-handed judicial control of settlement and the use of devices such as informal mini-trials, while others have rejected them. Some courts of appeals have permitted judges to require the parties to resort to alternative dispute resolution methods, while others have rejected such orders. Professor Shapiro's paper ably surveys this rapidly evolving field. ${ }^{68}$ The best we can say about Rule 16 is that it is ripe for

Bs See F. Easterbrook, Discovery as Abuse 16-18 (Aug. 13, 1988) (unpublished manuscript).

64 See P. Brodeur, Outrageous Misconduct: The Asbestos Industry on TRIAL 97-131 (1985) (relating how plaintiffs' attorneys amassed documentary evidence of a conspiracy to deny known health hazards of asbestos); Rosenberg, The Dusting of America: A Story of Asbestos - Carnage, Cover-Up, and Litigation (Book Review), 99 HaRv. L. Rev. 1693, 1696 (1986) (describing Brodeur's story as exemplifying the use of the discovery process to uncover and defeat a conspiratorial defense).

65 This suggestion was made orally at the conference held by the Civil Liability Program of the Center for Studies in Law, Economics, and Public Policy, Yale Law School, March 1988. Elliot argued that neither judges nor plaintiffs really know what is in defendants' documents, so defendants ought to decide what to reveal. After defendants' initial discretionary disclosure, the plaintiff would not request documents unless the cost of production was less than the expected value of the information. Such a theory stands investigative discovery on its head: for the most part, plaintiffs would be able to demand only that of which they already knew about.

${ }^{66}$ See Shapiro, supra note 45, at 1989-91. Curiously, one circuit, reputed to have a disproportionate share of anti-access judges, see supra note 50 , has rejected a trial judge's attempt to require resort to alternative dispute resolution. See Strandell v. Jackson County, 838 F.2d 884, 884 (7th Cir. 1988) (vacating a contempt judgment order for failure to participate in summary jury trial). 
judicial reconsideration. Having been amended so recently, the Rule is vulnerable to a myriad of new questions and new interpretations. It is quite possible that Rule 16 will soon become another focus of the access-exclusion struggle.

Beyond the Federal Rules, the "reformers" have urged exclusion on a number of other procedural fronts. Justice Scalia's penchant for tightening standing requirements results in restricting access to the federal courts. ${ }^{67}$ The use of abstention doctrines may seem rare enough, but it has raised sufficient concern to prompt a full report by the New York State Bar Association on the exclusionary effects of abstention on plaintiffs. ${ }^{68}$ Elimination of the power of federal courts to rely on state law in reforming state institutions under the Pennhurst doctrine tends to drive these cases from the federal courts. ${ }^{69}$ Habeas corpus cases bounce back and forth from federal to state courts under new doctrines requiring complete exhaustion or waiver. ${ }^{70}$

Even more important is the movement to abolish diversity jurisdiction. Legislation has been proposed which would eliminate diversity ex-

67 See Perino, Justice Scalia: Standing, Environmental Law, and the Supreme Court, 15 B.C. EnvTL. AfF. L. Rev. 135, 152 (1987) (characterizing Justice Scalia as viewing standing doctrine as a tool of judicial self-restraint); Note, Deference to Discretion: Scalia's Impact on Judicial Review of Agency Action in an Era of Deregulation, 38 Hastings L.J. 1223, 1231 (1987) (explaining the bases for Justice Scalia's strict views on standing); see also Winter, The Metaphor of Standing and the Problem of Self-Governance, 40 STAN. L. REv. 1371, 1373 (1988) (noting that the Burger Court's stiffened requirements for standing, which were imposed before Justice Scalia joined the bench, have increasingly restricted citizen's claims against the government).

${ }^{68}$ See N.Y. State Bar Ass'N, Report of the Comm. on Federal Courts, The Abstention Doctrine: The Consequences of Federal Court Deference To State Court Proceedings (Aug. 30, 1988) (concluding that abstention is frustrating class-wide and institutional suits against state administrative systems violating federal rights).

${ }^{69}$ See Pennhurst State School \& Hosp. v. Halderman, 465 U.S. 89, 124-25 (1984) (holding that under the eleventh amendment, federal courts lack jurisdiction to enjoin state officials on the basis of state law); see also Society for Good Will to Retarded Children v. Cuomo, 652 F. Supp. 515, 518-26 (E.D.N.Y. 1987) (discussing problems with Pennhurst).

${ }^{70} 28$ U.S.C. $\$ 2254$ (b) (1982) requires exhaustion of state remedies before a federal court may issue a writ of habeas corpus. Supreme Court cases restricting the flow of habeas petitions on procedural grounds include Rose v. Lundy, 455 U.S. 509, 522 (1982) (holding that a district court must dismiss habeas corpus petition that contains both claims exhausted at the state level and unexhausted claims), and Brown v. Allen, 344 U.S. 443, 482-87 (1953) (holding that a failure to use a state's available remedy, absent interference or incapacity, bars federal habeas corpus). Recently a bill, S. 2301, 99th Cong., 1st Sess. (1986), proposed further exhaustion requirements and a one-year statute of limitations for habeas petitions (at present there is none). See Harris, Law and Order Idealogues Threaten Writ of Habeas Corpus, ManHaTTAN LAWYER, Sept. 27, 1988, at 10; see also Remington, Change in the Availability of Federal Habeas Corpus: Its Significance for State Prisoners and State Correctional Programs, 85 MICH. L. REv. 570, 575-79 (1986) (discussing various congressional proposals to limit the availability of federal habeas corpus review). 
cept in cases of mass injuries resulting from a single incident. ${ }^{71}$ Excising diversity jurisdiction would be radical surgery, far beyond what is required by current caseloads.

Diversity jurisdiction benefits the nation because, first, many federal courts are much better able than many state courts to handle the larger more complex cases that often arrive on diversity grounds. Federal courts almost always have better support and facilities; federal magistrates can manage complex, multi-party discovery and federal courts and judges have extensive experience and significant invested talent in handling these large cases.

Second, federal judges with life tenure and unshrinkable salaries-except by inflation-are immune to the political influences and entanglements that often beset state court elective office. West Virginia State Supreme Court Justice Richard Neely has argued eloquently that many diversity suits should never be decided by state court judges like himself because the state judges are too vulnerable to parochial interests. $^{72}$ Historically, diversity jurisdiction was created to avoid discrimination against out-of-state parties, and such discrimination might well revive if diversity cases are returned to state forums.

Third, state courts simply are overwhelmed already; sending a huge chunk of the federal caseload back to state courts would be a bleak disaster in a state like New York.

Finally, diversity serves an important cross-fertilizing function. Federal judges are kept abreast of state law and in touch with the real concerns of local citizens and businesses. Those smaller diversity cases are of real importance to the parties involved and it is healthy for federal judges to grapple with such cases from time to time. The smaller cases are often microcosms of larger problems and often focus the judge's thinking on these problems most effectively. At the least, diversity cases break the monotony of hearing Social Security appeals from sometimes stingy administrative law judges.

One argument for abolishing diversity is that diversity cases occasionally lead federal courts to "make" state law in arrogation of state

71 See H.R. 3152, 100th Cong., 1st Sess. (1987); H.R. 9622, 95th Cong., 2d Šess. (1978); see also Feinberg Urges Cut in Federal Caseload, N.Y.L.J., Sept. 9, 1988, at 1, col. 3 (reporting Second Circuit Chief Judge Feinberg's support for abolishing diversity jurisdiction); Frank, For Maintaining Diversity Jurisdiction, 73 YALE L.J. 7, 7 (1963) (opposing ALI proposals to eliminate fifty to sixty percent of diversity jurisdiction).

72 See R. Neely, The Product Liability Mess: How Business Can be ResCUED FRom the Politics of State Courts 40 (1988) (qualifying the above view with the observation that federal courts can have almost as much local bias as state courts). 
courts' rightful roles. ${ }^{73} \mathrm{My}$ own experience does not suggest that this is a serious problem.

One recent article is the epitome of the "reforms" urged by the anti-access movement. In an address to Albany Law School, Judge Miner laments the "tension" inherent in dual state and federal jurisdiction over certain areas of the law. ${ }^{74} \mathrm{He}$ believes this tension leads to states feeling rather put out, because every once in a while federal courts decide a case the state courts might have, rule that a state court violated a prisoner's rights, or enjoin a state court's unconstitutional proceedings. This excellent judge's remedy for what he sees as an unbearable "tension" is to abolish diversity, cut back on habeas writs, and make state adjudications almost immune to federal civil rights injunctions. One wonders whether the fourteenth amendment ought to be scrapped for all the distress it must be causing some state judges.

The upshot of all this exclusionary zoning in the federal courts is what one commentator has called a "counter-revolution" in civil procedure, a "movement to restore to defendants, particularly powerful establishment 'repeat player' defendants, traditional procedural advantages they lost by virtue of the Federal Rules' 'emphasis on full disclosure and decision on the merits." ready has established a beachhead in our highest court. Professor Coffee overstates it, but makes a point with some merit when he writes: "a series of recent Supreme Court decisions seem to have the one common denominator that the plaintiff's attorney always loses."76

The anti-access movement should be objectionable to everyone-liberals and conservatives alike-for three reasons. First, whatever the merits of reducing plaintiffs' rights, a system which denies those rights by procedural subterfuge is highly undesirable. Substantive rights should be debated in public, with a full airing of issues, and usually given or taken away only by the Congress or, in some few instances, the Supreme Court. Procedural machinations designed quietly to overload the litigation costs of plaintiffs have the effect of denying

${ }^{73}$ See Miner, The Tensions of a Dual Court System and Some Prescriptions for Relief, 51 ALB. L. REv. 151, 155 (1987) (noting that federal judges often must predict how the state high court would answer questions).

The argument also is made that abolishing diversity jurisdiction would save millions of dollars in federal funds. See A. Partridge, The Budgetary Impact of Possible Changes in Diversity JuRisdiction 7, 16 (Fed. Jud. Center 1988). The result of such a measure, however, would be to shift costs to the state court system, which is under even greater pressure and has even fewer resources than the federal system.

74 See Miner, supra note 73, at 154.

78 Risinger, supra note 56 , at 35.

${ }^{76}$ Coffee, supra note 26 , at 920 n.2. 
substantive rights, but without any of the procedural safeguards attached to public and legislative decision-making. ${ }^{77}$

Second, restricting access unfairly burdens the poor and the aggrieved. The advent of the Federal Rules swung the courthouse door open. They permitted the full development of public law cases and the prompt consideration of the merits. Parties could no longer rely on clever maneuvers, but were required to make their best cases on the merits and face a dispositive ruling or a trial. Federal litigation grew as the federal courts became increasingly hospitable to effective dispute resolution. That growth in the main seems in retrospect highly desirable since it provided the basis for a quantum jump towards equality in fact.

Swinging closed the courthouse door would do a great disservice to individuals and to society as a whole. "When we deprive a person of access to the ordinary courts, we are depriving him of something of value. We are also eroding a principle which is important to democratic life." ${ }^{\prime 78}$ In this sense open procedure is highly democratizing: the powerful cannot hide behind well-paid procedural sharps, but must stand before justice clothed only in the merits of their cases. The powerless can relieve at least some of their frustration with the thought that at least the courts remain equally open to them. ${ }^{79}$

Closing the courts also will distort important policies inherent in the law. If plaintiffs cannot sue tortfeasors easily, deterrence will be frustrated. If sanctions frighten away civil rights lawyers, those behaving in the shadow of the law will risk inflicting more insidious discrimination. If diversity jurisdiction is abolished, some state courts will be seriously strained while large complex cases impinging on many states will be conducted ineffectively. ${ }^{80}$

Third, restricting access to the courts is imprudent. Conservatives interested in conserving the legitimacy of the courts and the judiciary and in sustaining respect for the rule of law should realize that these

77 See J. Weinstein, supra note 7, at 6-7; Burbank, supra note 27, at 1473; Resnik, Due Process: A Public Dimension, 39 U. FLA. L. REv. 405, 419 (1987) (stating that the public should have a role in adjudication since it is an aspect of political life); Shapiro, In Defense of Judicial Candor, 100 HaRv. L. REv. 731, 737 (1987) (emphasizing that judicial candor is vital for limiting judicial power).

78 Chase, supra note 16 , at 83.

79 See Brotherhood of R.R. Trainmen v. Virginia, 377 U.S. 1, 7 (1964); NAACP v. Button, 371 U.S. 415, 429-30 (1963); Buchman, Of Arterial Passageways Through the Legal Process: The Right of Universal Access to Courts and Lawyering Services, 48 N.Y.U. L. REv. 595, 596 (1973); Lester, Contingent Fees 12 (1988) (unpublished manuscript).

${ }^{80}$ See Weinstein, Preliminary Reflections on the Law's Reaction to Disasters, 11 Colum. J. Envtl. L. 1, 5 (1986). 
values are dependent on the public's feeling that they are able to vindicate their rights. It was in fact the conservative supporters of the Rules Enabling Act who sought open access and uniform rules in order to restore the appearance of fairness. Pound felt strongly that the procedural mess of technical and confining rules substantially reduced respect for the courts. He had been a judge, as had his father. Pound had written in 1897 that "[e]verything which tends to restore the judiciary to its true position, which tends even in slight manner to give to it in the eyes of the public those long lost attributes of dignity, authority, and eminence, which belong of right to the common law judges, is opportune and welcome."

William Howard Taft and his successor as Chief Justice, Charles Evans Hughes, were unhappy with the low public esteem of the judiciary partly occasioned by obfuscating procedural rules. In Hughes' eyes, " $[t]$ he spectacle of a weak and incompetent judge in action, or in inaction . . . does more to undermine public confidence than abuse of the institution by hostile critics." 82 Both Hughes and Taft sought to save the courts by streamlining procedure, so that respect for judges and law would be restored at the grassroots level. Hughes also feared that if the courts remained a tangled mess, Congress might reach out to intrude on the independence of the judiciary. ${ }^{83}$

Thomas Shelton took the most political view of the prudential benefits that uniform rules could bestow upon the judiciary. The Soviet government had taken control of Russia only recently, and fear of a Marxist revolution in the industrialized West was not unfounded. Shelton had a real concern that litigants frustrated by arcane procedure might turn to Lenin:

this is one of the things that is making Bolshevists in this country; that frequently, a sensible man, a business man, a practical business man, sits in the courtroom and sees his case thrown out on a technicality that he can not understand, and does not know why it is necessary . . . ${ }^{84}$

Although there is little fear of domestic Bolshevism, concerns over

81 Pound, Wig $\mathcal{F}$ Gown, Neb. Legal News, July 31, 1897, at 5, quoted in Subrin, supra note 9 , at 944-45.

${ }_{82} 2$ Pusey, Charles Evans Hughes 684 (1951).

${ }^{83}$ See id. at 685.

84 Procedure in the Federal Courts: Hearings on H.R. 2377 and H.R. 90 Before the House Comm. on the Judiciary, 67th Cong., 2d Sess. 28 (1922) (statement of Thomas Shelton), quoted in Subrin, supra note 9, at 959; see also Subrin, supra note 9, at 955 (proponents and drafters of the first ABA Enabling Act "advocated simplified procedure as a means of improving democracy in order to reduce the cause for bolshevik and other radical attacks on the courts"). 
the prudence of restricting access are appropriate. The report of the 1976 Pound Conference opened with the following words:

We of the profession need a reminder now and then that fidelity to law is assured in a society only when people generally believe that law's processes are operating evenly and fairly. In the words of the Victorian Chancellor, Lord Herschell, "Important as it is that people should get justice, it is even more important that they be made to feel and see that they are getting it." 85

Around the same time I wrote that the "[i]ncreased availability of the courts to those with grievances as a result of providing lawyers for the poor and modifications of such doctrines as standing, mootness, abstention and justiciability, have provided a valuable escape valve, preventing explosive reactions during a period of boiling social change." 86

Once the courthouse door is shut, some groups may have no alternative but to storm the entire building. John Kennedy told a group of diplomats that "[t]hose who make peaceful revolution impossible will make violent revolution inevitable." John, Viscount Morley, wisely remarked that "[y]ou have not converted a man because you have silenced him," ${ }^{87}$ and no doubt blocking a rightholder's entry to the court will not leave her satisfied.

Restricting access to the courts is seriously misguided and shortsighted. It will not alleviate any real "litigation crisis." It will not give order to the quasi-uniform system of Federal Rules. It will not enhance the legitimacy of the legal system. What it will do is deprive individuals and society of important rights and heighten the disaffection and frustration that results from exclusion. Neither liberals nor conservatives should encourage the closing of the courthouse door.

Perhaps, then, the most important Federal Rule of Civil Procedure is not Rule 11 , or Rule 16 , or Rule 56 , or even Rule 1 . It is Rule 77 , which inadvertently embodies the spirit of the Rules in its declaration that: "The district courts shall be deemed always open . . . ."

The Federal Rules, important as they are, cannot carry the entire burden of a fair and just legal system. ${ }^{88}$ The system needs fair substan-

${ }^{85}$ Gossett, Segal \& Smith, Foreword to The Pound Conference, supra note 19 , at 10 .

${ }_{88}$ Weinstein, Some Reflections on the "Abusiveness" of Class Actions, 58 F.R.D. 299,300 (1973).

87 J. MORLEY, ON COMPromise 188 (1874).

88 One commentator has stated that:

The hope for the future lies in recognizing that procedural decisions require complex value choices no less controversial than those underlying 
tive law, adequate court personnel to handle the load, counsel available to the poor through legal aid and other institutions, and a bar, bench, and academic community that utilize our power as keepers of the law in trust for all the people.

There is, nonetheless, a bona fide and responsible challenge posed by those who would raise the barriers to the federal courts. Are there not suits that should be screened out promptly because they have no merit, because they burden the system without any substantial advantage to prospective plaintiffs, and because they add to the cost of defendants and the public unfairly? Is totally unbridled access necessary when adequate and cheaper options, such as state courts for smaller claims or mediation and other alternatives to expensive litigation, are or could be available? Can we keep increasing the number of trial judges, with the implication that we will change the character of the federal system and necessarily cut down the proportion of appeals that can be handled well? Are the state courts not as capable of rendering justice, and why should they not be utilized more fully to enforce state and even federal rights? Do federal judges need to be bridled?

Some of these questions have been with us since the debate on Article III and the first Judiciary Acts. In part, the answer may lie in the "mandatory jurisdiction" theory, under which the federal courts must hear every case in their Article III jurisdiction and reduction in jurisdiction is a purely Congressional option. The Federal Rules, perhaps, should be as open as they reasonably can be to cases where the courts have the power to entertain them. But what is "reasonable"? Here we must turn to the eminent and distinguished scholars and practitioners gathered here, who will help us see the outlines of answers for today and tomorrow. With you, I look forward to Geoffrey Hazard's summary of where we are heading in American civil procedure. ${ }^{8 \theta}$ And I look forward to the Centennial of these Federal Rules: may they endure as pillars of democracy.

substantive law and that those value choices in turn require the proceduralist to have thought through deeper jurisprudential questions concerning the nature of law and its relation to social life.

Bone, Mapping the Boundaries of a Dispute: Conceptions of Ideal Lawsuit Structure from the Field Code to the Federal Rules, 89 Colum. L. REv. 1, 118 (1989).

${ }^{89}$ See Hazard, Discovery Vices and Trans-Substantive Virtues in the Federal Rules of Civil Procedure, 137 U. PA. L. Rev. 2237 (1989). 


$$
\text { - }
$$

